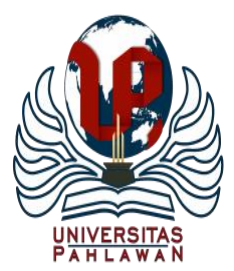

Jurnal Abdidas Volume 2 Nomor 3 Tahun 2021 Halaman 530-537

JURNAL ABDIDAS

http://abdidas.org/index.php/abdidas

\title{
Sosialisasi Pencegahan Penularan dan Penyebaran Covid-19 di Panti Asuhan Ecclesia
}

\author{
Januardin $^{1 凶}$, Holfian. D.T. Saribu ${ }^{2}$, Jarunjung Hutagaol ${ }^{3}$, Demak. C. Y. Simanjuntak ${ }^{4}$, Yois. N. Malau ${ }^{5}$ \\ Manajemen, Universitas Prima Indonesia, Indonesia, ${ }^{1,2,3,4}$ \\ Akuntansi, Universitas Prima Indonesia, Indonesia ${ }^{5}$ \\ E-mail: januardin@unprimdn.ac.id ${ }^{1}$, holfiandts@yahoo.co.id ${ }^{2}$, jarungjung13@gmail.com ${ }^{3}$, \\ yoisnelsarimalau@gmail.com ${ }^{4}$, claudiayoseph8@ gmail.com ${ }^{5}$
}

\begin{abstract}
Abstrak
Latar belakang sosialisasi pencegahan penularan dan penyebaran Covid-19 adalah akibat semakin meningkatnya penyebaran Covid-19, maka dari pada itu, untuk membantu memperingan tugas pemerintah pusat dan daerah, maka pengabdian kali ini diarahkan kepada sosialisasi pencegahan penularan dan penyebaran Covid-19. Tujuan dilakukannya pengabdian kepada masyarakat di Panti Asuhan Ecclesia adalah karena di panti asuhan ini belum pernah ada dari dinas manapun yang mensosialisasikan tentang Covid-19. Panti Asuhan Ecclesia terletak di Jl. Bersama II Pantai Delapan Ratus, Duren Jangak, Pancur Batu, Deliserdang. Metode sosialisasi yang dilakukan adalah dengan mempersentasikan materi lewat power point, mempraktikkan langsung materi yang disampaikan tersebut, dan adanya sesi tanya jawab sekilas materi sosialisasikan. Output yang didapatkan ketika kegiatan sosialisasi pencegahan penularan dan penyebaran Covid-19 adalah adanya antusias anak-anak panti asuhan dalam mengikuti kegiatan sosialisasi tersebut dan pengetahuan anak-anak panti asuhan semakin bertambah tentang bagaimana mencegah penularan dan penyebaran Covid-19 di panti asuhan dan dimana pun mereka melakukan aktivitasnya.
\end{abstract}

Kata kunci: sosialisasi, pencegahan, penularan, penyebaran, panti asuhan

\section{Abstract'}

The background of the dissemination of the prevention of transmission and spread of Covid-19 is due to the increasing spread of Covid-19, therefore, to help ease the duties of the central and regional governments, this time this service is directed towards disseminating the prevention of transmission and spread of Covid-19. The purpose of carrying out community service at the Ecclesia Orphanage is because at this orphanage no one has ever socialized about Covid-19. Panti Asuhan Ecclesia is located at jl. along with eight hundred beaches, duren jangak, pancur batu, deliserdang. The method of socialization is by presenting the material through powerpoints, practicing the material presented directly, and having a brief question and answer session on the socialization material. The output obtained during the socialization of the prevention of transmission and spread of Covid-19 was the enthusiasm of the orphanage children in participating in these socialization activities and the increasing knowledge of the orphanage children on how to prevent the transmission and spread of Covid-19 in the orphanage and elsewhere. they do their activities.

Keywords: socialization, prevention, transmission, prevention, orphanage

Copyright (c) 2021 Januardin, Holfian. D.T. Saribu, Jarunjung Hutagaol, Demak.

C. Y. Simanjuntak, Yois. N.Malau

$\triangle$ Corresponding author

Address : UNPRI MEDAN

Email : januardin@unprimdn.ac.id

ISSN 2721- 9224 (Media Cetak)

DOI : https://doi.org/10.31004/abdidas.v2i3.316

ISSN 2721- 9216 (Media Online) 
531 Sosialisasi Pencegahan Penularan dan Penyebaran Covid-19 di Panti Asuhan Ecclesia- Januardin, Holfian. D.T. Saribu, Jarunjung Hutagaol, Demak. C. Y. Simanjuntak, Yois. N.Malau

DOI: https://doi.org/10.31004/abdidas.v2i3.316

\section{PENDAHULUAN}

Akhir tahun 2019 hingga batas waktu yang belum pasti, dunia dilanda wabah virus Corona strain baru. Corona Virus Disease 2019 (COVID19) yang disebabkan oleh Severe Acute Respiratory Syndrome Corona Virus 2 (SARSCoV-2). Virus Corona ditemukan pada tahun 1930an (Hudson and Beaudette, 1932) dan menimbulkan wabah Severe Acute Respiratory Syndrome (SARS) yang mendunia pertama kali pada tahun 2002-2003. Virus Corona memiliki bentuk spherical atau pleomorphic dan merupakan genom RNA terbesar di antara virus RNA lainnya (Yang, Bartlam and Rao, 2006) (Belouzard et al., 2012).

Famili Coronaviridae terdiri dari 4 genus, yaitu: alphacoronavirus, betacoronavirus, gammacoronavirus dan deltacoronavirus. SARSCoV-2 seperti halnya SARS-CoV termasuk dalam genus betacoronavirus (Belouzard et al., 2012).

SARS-CoV-2 sebagaimana virus Corona yang telah ada sebelumnya merupakan virus yang termasuk dalam famili Coronaviridae. Virus RNA ini dapat menginfeksi unggas, mamalia dan manusia, kemudian menyebabkan penyakit akut hingga kronis (Weiss and Leibowitz, 2011)(Yang, Bartlam and Rao, 2006).

Sejak kasus pertama di Wuhan, terjadi peningkatan kasus COVID-19 di China setiap hari dan memuncak di antara akhir Januari hingga awal Februari 2020. Awalnya kebanyakan laporan datang dari Hubei dan provinsi di sekitar, kemudian bertambah hingga ke provinsi-provinsi lain dan seluruh China. Tanggal 30 Januari 2020, telah terdapat 7.736 kasus terkonfirmasi COVID-
19 di China, dan 86 kasus lain dilaporkan dari berbagai negara seperti Taiwan, Thailand, Vietnam, Malaysia, Nepal, Sri Lanka, Kamboja, Jepang, Singapura, Arab Saudi, Korea Selatan, Filipina, India, Australia, Kanada, Finlandia, Prancis, dan Jerman (Susilo, $d k k, 2020)$. SARS$\mathrm{CoV}$ merupakan betacoronavirus yang mempunyai posisi filogenetik yang unik yang kemudian dimasukan dalam subgenus Sarbecovirus (Luk et al., 2019).

Menurut Susilo, dkk (2020). COVID-19 pertama dilaporkan di Indonesia pada tanggal 2 Maret 2020 sejumlah dua kasus. Data 31 Maret 2020 menunjukkan kasus yang terkonfirmasi berjumlah 1.528 kasus dan 136 kasus kematian. Tingkat mortalitas COVID-19 di Indonesia sebesar $8,9 \%$, angka ini merupakan yang tertinggi di Asia Tenggara.

Menurut Handayani, dkk (2020), virus Corona merupakan zoonosis, sehingga terdapat kemungkinkan virus berasal dari hewan dan ditularkan ke manusia. Pada COVID-19 belum diketahui dengan pasti proses penularan dari hewan ke manusia, tetapi data filogenetik memungkinkan COVID-19 juga merupakan zoonosis. Perkembangan data selanjutnya menunjukkan penularan antar manusia (human to human), yaitu diprediksi melalui droplet dan kontak dengan virus yang dikeluarkan dalam droplet. Hal ini sesuai dengan kejadian penularan kepada petugas kesehatan yang merawat pasien COVID-19, disertai bukti lain penularan di luar Cina dari seorang yang datang dari Kota Shanghai, Cina ke Jerman dan diiringi penemuan hasil positif pada orang yang ditemui dalam kantor. Pada 
532 Sosialisasi Pencegahan Penularan dan Penyebaran Covid-19 di Panti Asuhan Ecclesia- Januardin, Holfian. D.T. Saribu, Jarunjung Hutagaol, Demak. C. Y. Simanjuntak, Yois. N.Malau

DOI: https://doi.org/10.31004/abdidas.v2i3.316

laporan kasus ini bahkan dikatakan penularan terjadi pada saat kasus indeks belum mengalami gejala (asimtomatik) atau masih dalam masa inkubasi. Laporan lain mendukung penularan antar manusia adalah laporan 9 kasus penularan langsung antar manusia di luar Cina dari kasus index ke orang kontak erat yang tidak memiliki riwayat perjalanan manapun.

Penularan virus Corona terjadi secara droplet atau melalui percikan saat orang batuk atau berbicara, hal inilah yang menyebabkan virus ini mudah sekali menular ke orang lain ( $\mathrm{Wu}$ et al., 2020). Tanda dan gejala yang tidak spesifik juga menyebabkan infeksi virus ini susah dikenali. Sebagian besar kasus infeksi Corona virus memiliki tanda dan gejala seperti influenza seperti demam, batuk, pilek, pusing dan dalam kondisi berat bisa mengalami sesak napas yang berat $(\mathrm{Wu}$ et al., 2020; Zhang et al., 2020).

Tenaga Relawan covid-19 termasuk salah satu unsur yang terlibat dalam pengendalian pencegahan penularan virus Corona ini. Sebagai tenaga relawan maka harus memahami bagaimana penularan virus Corona dan tindakan untuk mencegah penularan tersebut.

Menurut Departemen sosial RI (2014), panti asuhan adalah suatu lembaga usaha kesejahteraan sosial pada anak terlantar dengan melaksanakan penyantunan dan pengentasan anak terlantar, memberikan pelayanan pengganti orang tua atau wali anak dalam memenuhi kebutuhan fisik, mental dan sosial kepada anak asuh sehingga memperoleh kesempatan yang luas, tepat dan memadai bagi pengembangan kepribadiannya sesuai dengan yang diharapkan sebagai bagian dari generasi penerus cita-cita bangsa dan sebagai insan yang akan turut serta aktif dalam bidang pembangunan nasional.

Menurut data Kemenkes RI per 16 Februari 2020 diperoleh data COVID-19 yang positif adalah sebanyak 1.233 .959 dimana terjadi penambahan yang positif adalah sebayak 10.029 orang, yang sembuh sebanyak 1.039.674 dimana terjadi penambahan yang sembuh adalah sebanyak 7.609 orang, yang meninggal yaitu sebanyak 33.596 dimana terjadi penambahan sebanyak 229 orang. Jumlah yang suspek yaitu sebanyak 86.960 , specimen sebanyak 28.167, dan kasus aktif yaitu 160.689. Dari data tersebut dapat disimpulkan terjadinya peningkatan penyebaran penularan Covid-19 yang sangat signifikan.

Menurut Silitonga, dkk (2021), penyebaran virus Corona atau COVID-19 di Indonesia harus ditekan semaksimal mungkin. Kurangnya pemahaman masyarakat kota medan tentang pentingnya 3M (Memakai masker, Mencuci tangan, dan Menjaga jarak). Maka untuk itu diperlukan "Sosialisasi Penerapan 3M dalam Upaya Pencegahan Penularan Covid-19 pada Masyarakat Kota Medan”. Metode yang dilakukan adalah a) melakukan komunikasi, informasi dan edukasi perubahan perilaku $3 \mathrm{M}$ di RW/RT dan Desa/Kelurahan yang telah ditentukan sebagai lokus prioritas kegiatan mitigasi perubahan perilaku, b) melakukan kerja sama dengan pihak pihak terkait (Gugus Tugas Desa, Kader/Lurah, RW/RT, tokoh-tokoh masyarakat/adat/agama) dalam kegiatan mitigasi perubahan perilaku 3M di Desa/Kelurahan yang telah ditentukan sebagai lokus prioritas kegiatan mitigasi perubahan 
533 Sosialisasi Pencegahan Penularan dan Penyebaran Covid-19 di Panti Asuhan Ecclesia- Januardin, Holfian. D.T. Saribu, Jarunjung Hutagaol, Demak. C. Y. Simanjuntak, Yois. N.Malau

DOI: https://doi.org/10.31004/abdidas.v2i3.316

perilaku, c) melakukan pencatatan dan pelaporan kegiatan mitigasi perubahan perilaku 3M melalui sistem informasi yang telah disiapkan oleh Satgas Penanganan COVID-19 melalui aplikasi. Hasil yang terlihat pada saat para duta melaksanakan tugas, memang belum bisa dinilai keberhasilannya. Namun dari evaluasi jangka pendek yang terlihat setelah melakukan wawancara langsung, masyarakat pada umumnya sudah memahami dan langsung mau mengikuti anjuran para duta. Evaluasi jangka panjang tentu tidak bisa dinilai karena para duta tentu tidak lagi melihat orang yang pernah diwawancarai.

Panti asuhan Ecclesia merupakan salah satu panti asuhan yang lokasinya berada di Jl. Bersama Ii Pantai Delapan Ratus, Duren Jangak, Pancur Batu, Deliserdang. Panti asuhan ini jauh dari pusat keramaian dan jauh dari perhatian pemerintah, di panti asuhan ini menampung berbagai suku dan ras, dimana dari seluruh anak panti yang ada $60 \%$ nya adalah benar-benar yatim piatu (tidak punya orang tua dan keluarga), dan proses pembinaan yang dilakukan di panti asuhan tersebut sangatlah ketat dan disiplin. Di Panti Asuhan Ecclesia ini dari ketika dilakukan survei pendahuluan, kurangnya pengetahuan untuk menerapkan protokol kesehatan seperti yang ditekankan oleh Gugus Tugas Satgas Covid-19 yaitu 3M (Menjaga jarak, Memakai masker, dan Mencuci tangan). Tidak ada dari pihak manapun yang pernah mensosialisasikan tentang Pandemik COVID-19 dan bagaimana cara pencegahannya.

Identifikasi masalah yang ditemukan adalah terjadi peningkatan penyebaran penularan COVID19 di Indonesia dan di panti asuhan tidak pernah dilakukan sosialisasi tentang Covid-19 dan bagaimana cara pencegahannya supaya tidak terjadi penularan, ini dapat kita lihat dari aktivitas mereka kurangnya pengetahuan yang benar tentang seperti apa itu COVID-19 dan bagaimana cara mencegahnya supaya tidak terjadi penularan dan penyebaran.

Maksud dilakukannya sosialisasi pencegahan penularan dan penyebaran COVID-19 ini adalah perpanjangan tangan Pemerintah Pusat dan Pemerintahan Daerah Sumatera Utara dalam menjangkau daerah-daerah mensosialisasikan pencegahan penularan dan penyebaran COVID-19 supaya memutus rantai penyebaran penularan.

Secara umum tujuan kegiatan pengabdian kepada masyarakat di Panti Asuhan Ecclesia adalah untuk memsosialisasikan pencegahan penularan dan penyebaran COVID-19 di panti asuhan. Tujuan Khusus yang hendak dicapai adalah untuk memberikan informasi mengenai apa itu COVID-19 dan bgaimana pencegahannya agar tidak terjadi penularan dan penyebarannya.

\section{METODE}

a. Lokasi dan waktu Kegiatan

Adapun lokasi pengabdian kepada masyarakat ini adalah dilaksanakan di Panti Asuhan Ecclesia Jl. Bersama II Pantai Delapan Ratus, Duren Jangak, Pancur Batu, Deliserdang. Waktu kegiatan pengabdian kepada masyarakat dilaksanakan pada tanggal 17 Februari 2021 di Gedung Aula Panti Asuhan Ecclesia.

Jenis Kegiatan: adapun jenis kegiatan yang dilakukan adalah pengabdian kepada 
534 Sosialisasi Pencegahan Penularan dan Penyebaran Covid-19 di Panti Asuhan Ecclesia- Januardin, Holfian. D.T. Saribu, Jarunjung Hutagaol, Demak. C. Y. Simanjuntak, Yois. N.Malau

DOI: https://doi.org/10.31004/abdidas.v2i3.316

masyarakat ini adalah "Sosialisasi Pencegahan Penularan dan Penyebaran COVID-19”.

b. Persiapan Kegiatan

Adapun persiapan kegiatan pengabdian kepada masyarakat yang telah dilakukan adalah:

1. Kegiatan survei rencana tempat pengabdian kepada masyarakat di dua lokasi, tetapi tempat pengabdian kepada masyarakat yang putuskan adalah di Panti Asuhan Ecclesia.

2. Permohonan izin kepada Ketua Yayasan Panti Asuhan Ecclesia di Jl. Bersama II Pantai Delapan Ratus, Duren Jangak, Pancur Batu, Deliserdang.

3. Pengurusan surat- menyurat dari LPPM Universitas Prima Indonesia ke Yayasan Panti Asuhan Ecclesia.

4. Persiapan alat dan bahan-bahan yang akan digunakan di Panti Asuhan Ecclesia.

5. Persiapan tempat sosialisasi.

c. Peserta

Peserta yang mengikuti sosialisasi pencegahan penularan dan penyebaran COVID19 adalah anak Panti Asuhan. Jumlah peserta yang mengikuti kegiatan sosialisasi tersebut adalah sebanyak 33 orang.

d. Metode Sosialisasi

Adapun metode sosialisasi yang akan dilakukan adalah

1. Pembukaan dan perkenalan.

2. Acara ibadah.

3. Kegiatan sosialisasi.

a. Sosialisasi mengenai latar belakang COVID-19.

b. Sosialisasi mengenai masker dan cara menggunakannya. Sosialisasi mengenai menjaga jarak danpraktiknya.

c. Sosialisasi mengenai mencuci tangan dan praktiknya.

4. Penutup

\section{HASIL DAN PEMBAHASAN}

1. Pembukaan dan perkenalan antara dosen, dengan pengurus panti dan dengan anak Panti Asuhan Ecclesia. Dalam pembukaan acara kegiatan pengabdian kepada masyarakat di Panti Asuhan Ecclesia, salah satu dari dosen menyampaikan kata pembuka dan menjelaskan tujuan para dosen datang ke panti asuhan tersebut adalah untuk melakukan Tri Darma Perguruan Tinggi. Setelah kata pembuka, kemudian para dosen memperkenalkan diri masing-masing kepada anak panti asuhan dengan canda dan tawa, agar suasana tidak terlalu tegang.

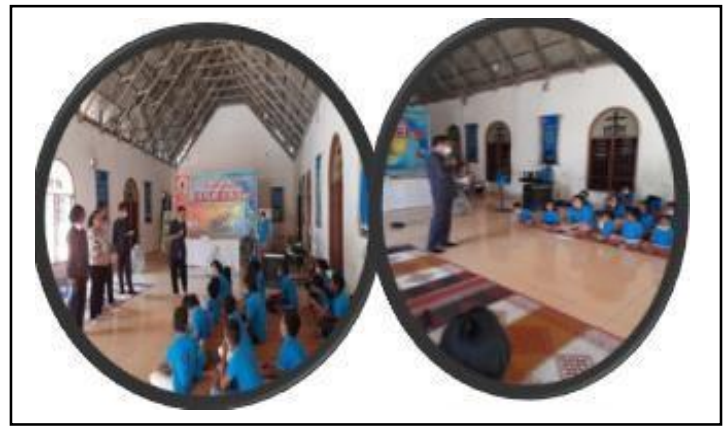

Gambar1. Pembukaan dan Perkenalan

2. Acara ibadah, setelah pembukaan dan perkenalan, acara selanjutnya adalah para dosen mengajak peserta (anak panti) untuk melakukan acara ibadah atau kebaktian dulu. Adapun kegiatan ibadah yang dilakukan adalah doa pembuka, bernyanyi, 
535 Sosialisasi Pencegahan Penularan dan Penyebaran Covid-19 di Panti Asuhan Ecclesia- Januardin, Holfian. D.T. Saribu, Jarunjung Hutagaol, Demak. C. Y. Simanjuntak, Yois. N.Malau

DOI: https://doi.org/10.31004/abdidas.v2i3.316

membaca Firman Tuhan, bernyanyi, dan doa penutup.

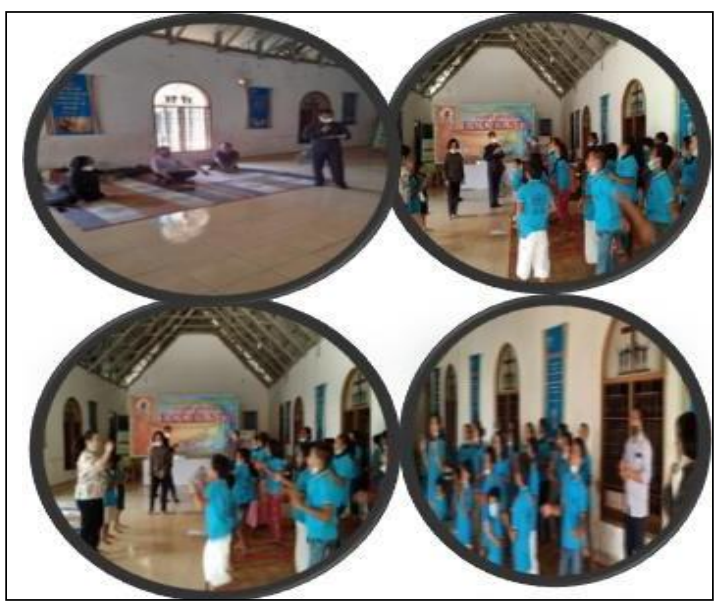

Gambar 2. Acara Ibadah

3. Kegiatan sosialisasi, setelah acara ibadah, kegiatan selanjutnya adalah masuk kepada tujuan utama melakukan pengabdian kepada masyarakat yaitu kegiatan "Sosialisasi Pencegahan Penularan dan Penyebaran COVID-19".

a. Mensosialisasikan latar COVID-19 yaitu apa itu COVID-19, negara awal terjadinya COVID-19, data update laporan COVID-19, dan tujuan dilakukan sosialisasi.

b. Mensosialisasikan tentang masker yaitu menjelaskan jenis-jenis masker, tujuan memakai masker, manfaat memakai masker, cara memakai masker (dengan dipraktikkan oleh salah satu dosen dan beberapa anak panti), dan lainnya.

c. Mensosialisasikan tentang menjaga jarak yaitu menjelaskan tujuan menjaga jarak, jarak yang efektif atau yang direkomendasi oleh dinas kesehatan (dengan dipraktikkan oleh dosen dan beberapa anak panti), dan lainnya.

d. Mensosialisasikan tentang mencuci tangan yaitu menjelaskan tujuan mencuci tangan,mengapa penting mencuci tangan, cara mencuci tangan yang benar, (dengan dipraktikkan oleh salah satu dosen dan beberapa anak panti), dan lainnya.

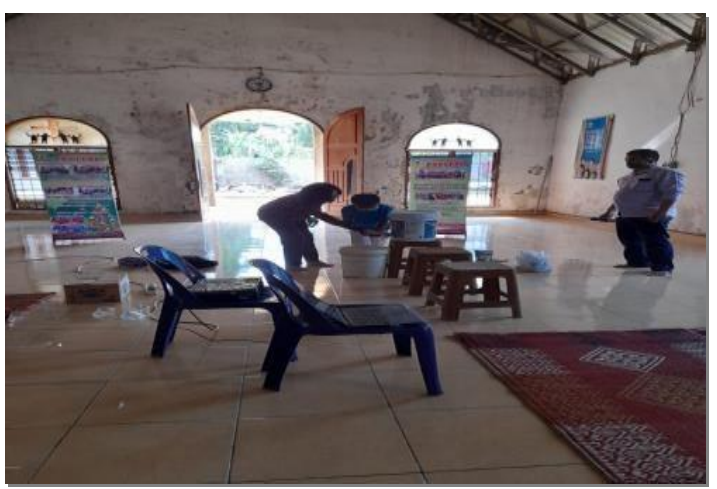

Gambar 3. Sosialisasi Mencuci Tangan

e. Kegiatan tanya jawab. Kegiatan tanya jawab dilakukan tentang pengetahuan COVID-19 yang telah disosialisasikan tadi, untuk menguji sudah sejauh mana anak panti memahami cara pencegahan penularandan penyebaran COVID-19, ini dilakukan setelah materi sosialisasi selesai disampaikan melalui power point dan praktik. Dalam sesi tanya jawab ini dosen memberikan hadiah kepada anak panti yang berhasil menjawab pertanyaan yang dberikan kepada anak panti.

4. Kata penutup dari dosen dan dari Ketua Yayasan Ecclesia serta penyerahan alat dan bahan-bahan yang dibutuhkan dalam mencegah penularan dan penyebaran COVID-19 (seperti: masker, sabun cair, 
536 Sosialisasi Pencegahan Penularan dan Penyebaran Covid-19 di Panti Asuhan Ecclesia- Januardin, Holfian. D.T. Saribu, Jarunjung Hutagaol, Demak. C. Y. Simanjuntak, Yois. N.Malau

DOI: https://doi.org/10.31004/abdidas.v2i3.316

galon tempat air untuk cuci tangan), serta dosen menyerahkan sembako sebagai bantuan pribadi para dosen, dan kemudian foto-foto bersama anak panti.

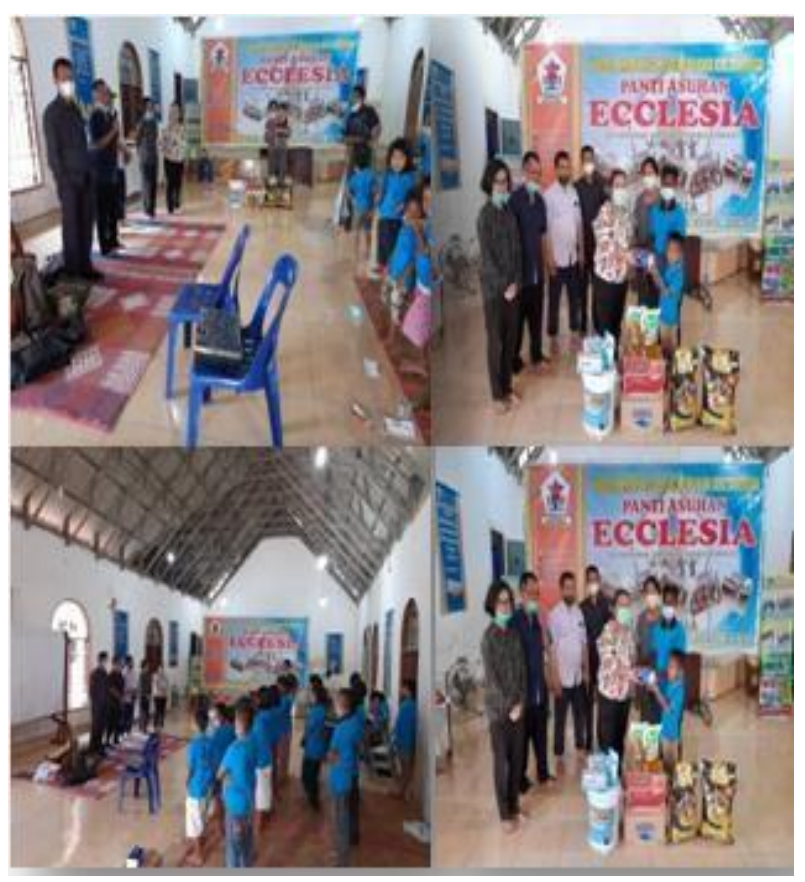

Gambar 4. Acara Penutup dan Penyerahan Cindera Mata

Dari kegiatan sosialisasi pencegahan penularan dan penyebaran COVID-19, hasil yang diperoleh adalah bahwa kegiatan tersebut membantu Gugus Tugas COVID-19 menjangkau daerah-daerah yang tidak terjangkau dalam mensosialisasikan pentingnya pengetahuan $3 \mathrm{M}$, guna menekan peyebaran penularan COVID-19. Dengan adanya sosialisasi tersebut anak Panti Asuhan Ecclesia menjadi memahami bagaimana cara menggunakan masker yang benar dan apa manfaatnya, bagaimana cara menjaga jarak yang benar dan apa manfaatnya, dan memahami cara mencuci tangan yang benar dan apa manfaatnya.

Ketercapaian tujuan kegiatan adalah pengetahuan anak-anak panti asuhan bertambah mengenai bagaimana mencegah tejadinya penularan COVID-19 yaitu dengan $3 \mathrm{M}$ (Memakai masker, Menjaga jarak, dan Mencuci tangan), yang mana selama ini belum ada dari pihak manapun yang pernah datang untuk mensosialisasikan tentang COVID-19 dan $3 \mathrm{M}$, dengan begitunya kegiatan sosialisasi ini juga dapat menekan penyebaran COVID-19. Ketercapaian tujuan lainnya adalah kegiatan Tri Dharma Dosen dapat terlaksana dengan baik dan lancar.

\section{SIMPULAN}

Kegiatan pengabdian kepada masyarakat sosialisasi pencegahan penularan dan penyebaran COVID-19 di Panti Asuhan Ecclesia Jl. Bersama II Pantai Delapan Ratus, Duren Jangak, Pancur Batu, Deliserdang membantu Gugus Tugas COVID-19 menjangkau daerah-daerah yang tidak terjangkau dalam mensosialisasikan pentingnya pengetahuan $3 \mathrm{M}$, guna menekan penyebaran penularan Covid-19. Anak panti asuhan Ecclesia menjadi memahami bagaimana cara menggunakan masker yang benar dan apa manfaatnya, bagaimana cara menjaga jarak yang benar dan apa manfaatnya, dan memahami cara mencuci tangan yang benar dan apa manfaatnya.

\section{UCAPAN TERIMA KASIH}

Penulis mengucapkan terima kasih kepada Yayasan Ecclesia yang telah menerima kami melakukan sosialisasi. Penulis juga mengucapkan terima kasih kepada pihak UNPRI yang telah mengizinkan kami melakukan kegiatan pengabdian kepada masyarakat tentang 
537 Sosialisasi Pencegahan Penularan dan Penyebaran Covid-19 di Panti Asuhan Ecclesia- Januardin, Holfian. D.T. Saribu, Jarunjung Hutagaol, Demak. C. Y. Simanjuntak, Yois. N.Malau

DOI: https://doi.org/10.31004/abdidas.v2i3.316

"Sosialisasi Pencegahan Penularan dan

Penyebaran Covid-19 di Panti Asuhan Ecclesia"

\section{DAFTAR PUSTAKA}

Belouzard, S. et al. (2012). Mechanisms of coronavirus cell entry mediated by the viral spike protein. Viruses. doi: 10.3390/v4061011.

Departemen Sosial Republik Indonesia. (2014). Acuan Umum Pelayanan Sosial Anak di panti sosial asuhan anak. Jakarta : Departemen Sosial RI.

Handayani, D., Hadi, R.D., Isbaniah, F., Burhan, E., dan Agustin,H. ( 2020). Penyakit Virus Corona 2019. Departemen Pulmonologi dan Kedokteran Respirasi Fakultas Kedokteran Universitas Indonesia,. Rumah Sakit Umum Pusat Persahabatan, Jakarta. Jurnal Respirologi Indonesia, 40 (2), 119-129.

Hudson, C. B. and Beaudette, F. R. (1932). Infection of the cloaca with the virus of infectious bronchitis. Science. doi: 10.1126/science.76.1958.34-a.

Luk, H. K. H. et al. (2019). Molecular epidemiology, evolution and phylogeny of SARS coronavirus. Infection, Genetics and Evolution. doi: 10.1016/j.meegid.2019.03.001.

Susilo, A., Rumende, M.C., Pitoyo,W.C., Santoso, W.D., M,Yulianti., Herikurniawan, H., Sinto,R., $\quad$ Singh,G., $\quad$ Nainggolan,L., Nelwan,J.E., $\quad$ Chen,L.K., Widhani,A., Wijaya,E., Wicaksana,B., Maksum,M., Annisa,F., Jasirwan,O.M.C. dan Yunihastuti.E. (2020). Coronavirus Disease 2019: Tinjauan Literatur Terkini. Jurnal Penyakit Dalam Indonesia, 7(1), 45-67.

Weiss, S. R. and Leibowitz, J. L. (2011). Coronavirus pathogenesis. 1st edn, Advances in Virus Research. 1st edn. Elsevier Inc. doi: 10.1016/B978-0-12- 385885-6.00009-2.

$\mathrm{Wu}, \mathrm{C}$. et al .(2020). Analysis of therapeutic targets for SARS-CoV-2 and discovery of potential drugs by computational methods. Acta Pharmaceutica Sinica B. doi: 10.1016/j.apsb.2020.02.008.
Zhang, L., Lin, D., Sun, X., Curth, U., et al. (2020). Crystal structure of SARS-CoV-2 main protease provides a basis for design of improved a-ketoamide inhibitors. Science. doi: 10.1126/science.abb3405. 